\title{
Optimizing Government Policies On Profession Zakat
}

\author{
Nur Mohamad Kasim \\ Faculty of Law Universitas Negeri Gorontalo \\ nurkasim76@yahoo.co.id
}

\begin{abstract}
The significant potential of zakat on profession needs to be actualized through a clear regulation. The targets of zakat on profession are: Ministry or State Institutions, Local Government, State-owned Enterprises, Local Government Owned Enterprises, even other professions that have a high income. The government's efforts to facilitate zakat on profession are solely aimed at making the mechanism of zakat management to be good, transparent and integrated into a system. However, zakat levies should have a specific rule that is binding all citizens, especially all Muslim Civil State Apparatus (henceforth called as ASN) who certainly meets the applicable regulations. For those who have income and already reach nishab or nominal income limit must pay zakat, while the ones whose incomes do not reach nishab are not obliged to do such a thing. Gorontalo province is one of the regions whose population is predominantly Muslim and has potential in terms of Islamic valuesbased economic development. Therefore, there needs to be a strict regulation to regulate zakat on profession, so that the utilization of zakat can help to alleviate the burden of the poor. By the existence of regulation, people who pay and receive zakat are equally having the benefits of zakat. This is to say that government has a prominent role and responsibility in optimizing the enactment of zakat on profession since the reality of the most significant zakat received by BAZNAS (Islamic board which oversees the collection of Zakat) in Gorontalo province is from ASN and other professions income.
\end{abstract}

Kata Kunci: Optimization, Policy, Zakat on Profession 


\section{Introduction}

In Indonesia, zakat management is not only regulated by religious law but also in state law. The state in this case the government has the obligation to regulate the legal aspects of zakat management. Law No. 23 of 2011 on the Management of Zakat in lieu of Law No. 38 of 1999 provides evidence that the concept of zakat becomes an important instrument in the management of state finance and economy. In particular, the implementation of the Law is regulated in Government Regulation No. 14 of 2014.

Today, many people have not understood the benefit of zakat. Most people are not even aware that they are obliged to pay zakat. A few of them understand that zakat is only performed in Ramadan (zakat fitrah). This condition is caused by the lack of knowledge about profession zakat.

Zakat has a significant potential for Islamic financial instrument. If properly managed, this zakat will generate a significant income to support people's economy and income distribution. This will be beneficial if the government can cope with the problem of poverty, at least the annual poverty rate in each region will gradually decrease.

One of the crucial tasks of the government in the field of economy is to free the society from the shackles of poverty and improve the welfare of the community fairly. In this regard, Didin ${ }^{1}$ argues that poverty alleviation aims to create a prosperous and just society. The welfare indicator is free from kufr, hunger, idolatry, and fear.

According to Didin Hafiduddin, profession zakat is the zakat imposed on each job or profession expertise, either done alone or with other people or institutions that bring income (money) that meet nisab. The form of income that most often generates wages or big salaries today are obtained from professions such as doctors, advocates, motivators, designers, judges, civil servants, and so forth (Qardhawi 1996, 459).

Since the province of Gorontalo is a region dominated by the Muslim population, it has potential in terms of economic development based on Islamic values. The need for strict regulation to regulate the profession zakat is essential so that the utilization of zakat can help alleviate the burden of the poor. With a precise regulation, both zakat payers (muzakki) and the person receiving the zakat (mustahiq) share the benefits of the zakat.

The revenue of zakat received by BAZNAS of Gorontalo Province is mostly derived from profession zakat. This is because the income coming from civil servants in the province of Gorontalo is enormous and this provides tremendous potential for improving the welfare of the community. If the collection and utilization profession zakat can be improved from year to year, this can reduce the problem of poverty in Gorontalo province. Poverty has become a serious problem faced by the community and even the people of Indonesia as a whole. By that, the problem can be overcome by the local government through profession zakat.

\footnotetext{
al-ạ̣kām vol. 3, Nomor 2, 2018
} 
The function of zakat must be realized and improved so that zakat can be beneficial to society (Asnaini 2008, 3). To obtain the benefits in the fulfillment of zakat function as an asset of welfare development of ummah, zakat management needs to be taken into account. Zakat in its implementation shall be determined and regulated by religion and state government, in terms of the type of zakat by the obliged person and the zakat receiver (mustahiq) up to the management by a third party, which in this case, is the government or institution appointed by government to manage zakat for the sake of mutual benefit. It is this state or institution that will help muzakki to deliver his zakat to the mustahiq or help the mustahiq to receive his rights (Asnaini 2008, 2).

Based on the above description, the focus of the study is to answer the question "what is the government's policy towards profession zakat?" The purpose of this study is to find out and analyze government policies related to profession zakat. While the benefits of his research are

1). to provide a critical contribution in terms of science, especially the science of Islamic law, as well as to local governments in solving legal issues related to profession zakat.

2). to design a model of a policy framework that can provide solutions for local governments related to profession zakat in supporting the improvement of people prosperity in Gorontalo

\section{Theoretical framework}

a. Welfare State

The welfare state is an ideal model of development focused on improving welfare by providing a more important role to the state in providing universal and comprehensive social services to its citizens. Paul Spicker states that the welfare state stands for a developed ideal in which welfare is provided comprehensively by the state to the best possible standards (Spicker 1995).

Based on Law Number 11 of 2009 Articles 1 and 2 that social welfare is a condition of the fulfillment of decent living needs for the community, so as to develop themselves and can carry out social functions that can be done by the government, local government and society in the form of social services which include social rehabilitation, social security, social empowerment, and social protection.

The state has an obligation to pay attention to two kinds of needs, namely material and spiritual needs. To realize the principle of welfare, the Koran has formulated with the phrase "Baldatun Tayyibatun Wa Rabbun Ghaffur", which is a prosperous country under the pleasure of Allah SWT. In essence, the state is obliged to organize and allocate funds in large quantities for the needs of the community, especially for people who are classified as weak. 
In addition, the welfare state provides welfare services to all people, both rich and poor in a fair and equitable manner without discrimination.

b. Justice theory

Profession zakat is zakat charged on every profession job, therefore there is obligatory on all kinds of income. In addition, profession zakat reflects the sense of justice.

Justice in the view of Yusuf Qardhawi is to grant an individual of his rights, either individually or in the congregation, or in any manner without exceeding or reducing, so as not to undermine his rights and not to abuse the rights of others (Kasim 2011, 79).

c. Management theory

According to Soekanto, management is a process that starts with the process of planning, arrangement, supervision, driving up to the process of realization of goals. Suharsimi Arikunto says that the word "Management" can be likened to management, which also means arrangement or management (Arikunto 1993, 31).

From the above observations, it can be concluded that management is not only implementing an activity that includes management functions, such as planning, implementation, and supervision to achieve the objectives effectively and efficiently. However, also, it involves a process to achieve a goal.

\section{Research method}

This is legal research that will examine and analyze legal issues related to government policy towards profession zakat. This study uses a statutory approach, conceptual approach or legal theory and case approach. In addition, data collection techniques were carried out through literature, observation, and interviews.

\section{Basic pillar of profession zakat policy}

Profession zakat has become a new problem. The type of profession zakat is quite promising, due to the income from the profession that can make someone rich and have excess property. Therefore, in its implementation, zakat must be regulated by the government as the policy maker to be able to establish and enforce it as well as to create proper management of the zakat.

It is admitted that there has been a difference of opinion among the Muslims. This issue can be solved through regulation from the government. Therefore, the Law number 20 of 2011 on the zakat management and the regulation of the religious affairs minister number 52 of 2014 can be set as the underlying law of the profession zakat.

According to the minister of religious affairs, Lukman Hakim Saifuddin, that zakat reinforcement that is derived from the Muslim civil servants' monthly salary is not a new

al-aḥkām vol. 3, Nomor 2, 2018 
thing that has just been implemented as there are a number of provinces in Indonesia that have regulated and implemented the profession zakat. In addition, the Muslim zakat reinforcement has been stipulated in Law number 23 of 2011 on zakat management, government regulation number 14 of 2014 on zakat implementation, presidential instruction number 3 of 2014 optimizing zakat collection at ministerial and state offices, local government, BUMN/BUMD, and ministerial regulation of religious affairs number 52 of 2014 on terms and calculation management of Mal and Fitrah zakat. However, all of these regulations have not been integrated into one transparent and good management system (Press Conferene at Kemenag Building, February 7, 2018).

The mechanisms of zakat management collected from various professions including Muslim civil servants have not been properly implemented, so that the collected funds devoted to the utilization of the community's economy and to improve the welfare of the community have not been fully implemented properly. This is because the institution assigned to collect and manage profession zakat from the Muslim civil servants needs to be arranged so that the collection and distribution are well directed. This policy applies to the profession and Muslim civil servants because the government needs to facilitate the professions or the muzakki to fulfill its obligations

The zakat obligation for the muzzaki is imposed for those who have required minimum income. For those who have not reached the minimum income to pay zakat, it is not obliged for them to pay zakat. Importantly, the state must play an important role in facilitating its people especially those who are Muslims to obtain the ease in doing their obligation to pay zakat. This is one of the state's responsibility to prosper its people and overcome poverty in Indonesia.

The government needs to be careful in formulating policies on profession zakat. There are many things that need to renewed in terms of regulation regarding the salary cut for the Muslim civil servants and other professions that are considered capable of paying zakat. Also, the government should rearrange the mechanism of zakat collection for the Muslim civil servants and other bodies that have been assigned to collect and manage the profession zakat. This is expected to create a better zakat management in the future.

\section{The principles of Good Governance}

Good Governance relates to good governance management. Implementation of good governance relates to the implementation of the functions of state administration. This principle contains guidelines that should be used by stakeholders in this case law enforcers to test the legality of a legal act. The review of good governance not only deals with the functions of state administration, but also includes the other branches of state power such as the establishment of law and law enforcement. 
A country that has good governance certainly provides various conveniences, certainty in providing services and protection from arbitrary actions both on self, rights and property. Therefore, it is very reasonable if the demands of good governance are primarily aimed at the renewal of law enforcement. Practically, the effort to realize good governance is none other than a clean government, providing convenience and various direct guarantees to the community. Also, good governance is nothing other than an effort to reform the system of state administration (bureaucracy) and law enforcement procedures.

In this information era, the governmental issues that are accommodated in the MPR Decree No. RI. XI / MPR / 1998 on the implementation of a clean and corrupt Free State, collusion and nepotism (henceforth referred to as KKN), and Law Number 28 of 1999 on the administration of clean country and KKN. Through this arrangement, the Indonesian nation affirmed its determination to always seriously realize the implementation of State government and development based on the principles of good governance.

With the enactment of Law Number 28 of 1999 on the administration of a clean and Free State of KKN, the general principles of good governance in Indonesia are identified in Article 3 formulated as the general principle of state administration, namely the principle of legal certainty, the principle of transparency, the principle of proportionality, professions, and accountability principles.

In addition, Article 5 of the Law on KKN and Article 3 paragraph (1) of MPR Decree No. XI / MPR / 1998 on the administration of a Clean and KKN-free Country, determines to avoid any form of corruption, a person who is entrusted to a position in the administration of the State shall oath according to his religion and shall announce and be willing to inspect his assets before and after taking office, without intention for the benefit of personal, family, or group and does not expect any kind of reward which is contrary to the prevailing laws and regulations as well as willing to witness in KKN and other cases in accordance with the provisions of applicable laws and regulations.

Thus, the general principles of good governance apply universally in some countries as an unwritten law. In Indonesia, with the enactment of Law Number 28 of 1999 which formulates the general principles of the implementation of the state formally binds the state organizers to be implemented in their duties and functions.

In regard to the collection and empowerment of zakat, the implementation of good governance principles is required as part of the State's economic management system to realize the objectives of the Republic of Indonesia, as well as to create a just and prosperous society. Therefore, the management of zakat should be placed as part of the implementation of a just economy.

Furthermore, the problems and needs of the community related to how to manage and empower the zakat in order to be enjoyed by the rightful and alleviate poverty 
should also be based on government administration in accordance with good governance principles. This is also related to the development of technology and management that can be accommodated in the implementation of zakat management administration. Therefore, there are demands to improve the quality of zakat services to be effective.

The state management is an important element of a country. The ineffectiveness of the Law No. 23 of 2011 on zakat management, including zakat collection may be the result of the lack of good management, particularly the offices that manage and collect zakat that do not abide with the good governance principles.

The issue of zakat management is closely related to the public's trust in this State organizer which actually underlies the birth of TAP MPR RI. XI / MPR / 1998 on the administration of a Clean and Free State of KKN and Law Number 28 of 1999 on the Implementation of a Clean and KKN-Free Country.

Therefore, the management of zakat should promote transparency built on the basis of free information flow. The entire process of zakat management, management institutions, and information needs to be accessible to interested parties, and the information available should be sufficient to be understandable and monitored by the community.

\section{Synergy of Local Government with BAZNAS Related to Profession Zakat Policy}

Talking about the implementation of profession zakat at least there is a relationship that exists between the governments with BAZNAZ. It is important for BAZNAS and LAZ to improve the accountability and transparency of zakat management, including the aspects of collection, distribution and utilization. With various efforts and breakthroughs that the quality of zakat management can be realized so that the utilization can be felt by all levels of society, especially mustahiq groups.

The function of the state in applying the principle of mutual obligation of the community actually reflects the role of the state in forcing its citizens to obey what has been stipulated in the provisions of Islamic law. This reflects the capacity of the state as the ruling authority which assumes the obligation to realize what has been stipulated in the Qur'an and the Prophet's Hadith. The state has the right to force each individual to fulfill his obligations and to perform what Allah has commanded.

On this basis, the state is directly responsible for the livelihoods of economically disadvantaged people. The immediate obligation to be done by the government is to ensure the lives of individuals to conform to the living standards of Islamic societies. The guarantees referred to are "guarantees of maintenance" as set forth in Article 34 of the 1945 Constitution. 
The zakat potential of Muslim civil servants can reach Rp 10 trillion per year, while the current zakat receipt is only Rp 6 trillion from the potential of all zakat revenue in this country of Rp 217 trillion. According to Minister of Religious Affairs Lukman Saifuddin, zakat funds derived from the salary of Muslim civil servants will be distributed for the benefit of society, both in the field of social, education, health to natural disasters. Most importantly the funds are not limited to the interests of Muslims only. In fact, there is a possibility of zakat funds will be used for infrastructure development. It depends on the charitable institution of zakat.

Therefore, the synergy between the government and BAZNAS is needed to improve people's welfare. Especially for people who are less able to get help both for consumption and production needs. Provincial Baznas, including those in the district and municipal Baznas offices shall conduct massive UPZ movement in accordance with Baznas Regulation No. 2 of 2016. In addition, Baznas should coordinate with the local governments to encourage and optimize zakat collection regulations and provision of APBD (regional budget) for operational costs of Baznas.

\section{Conclusion}

From the above description it can be concluded that the implementation of government policies related to profession zakat is very important, considering the type of zakat is potential to improve the welfare of the community. If all professions are willing to pay the zakat with $2.5 \%$ deduction from their income, the future potential of the profession zakat will bring positive impact on the zakat matters in Indonesia.

Optimizing the management of profession zakat can be realized by encouraging the government to immediately realize the policy about profession zakat by making regulations that can be binding for all professions either from the ASN to other professions that have more income. The collecting is strived for the government to arrange the management mechanism of profession zakat.

\section{REFERENCES}

\section{Books}

Asnaini. 2008. Zakat Produktif Dalam Perspektif Hukum Islam. Yogyakarta: Pustaka Pelajar.

Didin, Hafiduddin. Tanggapan Pada Seminar Kelompok Study Kajian Teori Ekonomi Dalam Islam, LIPI: Jakarta. 2014. Quoted in Jusmuliani, and Muhammad Soekarni, Kebijakan Ekonomi Islam. Yogyakarta: Kreasi Wacana, 2005.

Kasim, Nur Mohamad. 2011. "Zakat Profesi Dalam Perspektif Hukum Keuangan Publik". PhD diss., Universitas Muslim Indonesia, Makassar. 
Kasim, Nur Mohamad. 2017. "Contribution of Profession Zakat on Local Economic Development." International Journal of Business and Management Invention 6, no.5.

Mukti, Fajar, and Achmad Yulianto. 2010. Dualisme Penelitian Hukum Normatif dan Empiris, Yogyakarta: Pustaka Pelajar.

Niswatin, Roy Hasiru, and La Ode Rasuli. 2016. "Development Strategy of Islamic Economic, Business and Accounting in Gorontalo, Indonesia." International Journal of Economic Research 13, no.7.

Soerjono, Soekanto. 2004. Sosiologi Suatu Pengantar, 12. Jakarta: Raja Grafindo Persada.

Suharsimi, Arikunto. 1993. Prosedur Penelitian, 31. Jakarta: Rineka Cipta.

Spickers, Paul, Social Policy: Themes and Approaches, 82. London: Prentice Hall. 2008. Quoted in Edi Suharto, Islam dan Negara Kesejahteraan. (Jakarta). 2008.

Peter, Mahmud Marzuki. 2005. Penelitian Hukum Edisi Revisi. Jakarta: Kencana Prenadamedia Group.

Yusuf, Qardhawi. 1996. Hukum Zakat. Jakarta: Lentera Antar Nusa.

Yulianto, Agus. 2018. "Menag: Kami Hanya Fasilitasi Potongan Zakat.” Republika.co.id, (Jakarta), February 7, 2018. 
al-aḥām vol. 3, Nomor 2, 2018 